\title{
Tilt vibratory exercise improves pain, strength and somatosensory function in patients with fibromyalgia: A randomized controlled trial
}

\author{
José A Parraca, J ose C Adsuar, Pedro R Olivares, Borja del Pozo-Cruz, Narcis Gusi \\ Faculty of Sports Sciences, University of Extremadura, Caceres, Spain.
}

Correspondence: J osé A Parraca. Address: Faculty of Sports Sciences, University of Extremadura, Caceres, Spain. Email: jparraca@unex.es

Received: March 2, 2013

DOI : 10.5430/jnep.v4n2p104

\author{
Accepted: May 23, $2013 \quad$ Online Published: October 9, 2013 \\ URL: http://dx.doi.org/10.5430/jnep.v4n2p104
}

\begin{abstract}
The main objective of this study was to analyse the effects of 12 weeks of tilting whole body vibration therapy on pain, strength and somatosensory function in patients with fibromyalgia syndrome. This study was randomized controlled trial with assessor blinding. Thirty-six women with fibromyalgia were randomly allocated to exercise or control groups. The exercise group received a 12-week program of tilting whole body vibration therapy at $12.5-\mathrm{Hz}$ frequency and $3 \mathrm{~mm}$ amplitude. The Muscle strength was assessed with an isokinetic dynamometer, pain with a digital algometer and the somatosensory system with a stabilometry platform.

The treatment induced a $23.5 \%$ improvement in widespread pain $(P<.05)$ and $40 \%$ improvement in knee pain $(P<.05)$.

The concentric knee extension and flexion strength improved by greater than $19 \%(P<.05)$, and balance with eyes closed showed a $25 \%$ improvement in the overall stability index $(P<.05)$ and a $40 \%$ improvement in the antero-posterior stability index $(P<.05)$ for all positions evaluated.

Twelve weeks of tilting whole body vibration therapy 3 times a week at a frequency of $12.5 \mathrm{~Hz}$ could be an effective therapy to improve strength, somatosensory function and pain in women with fibromyalgia.

This article presents new approaches for management of strength, somatosensory function and pain in patients with fibromyalgia. These measures and these results could potentially help clinicians, physiotherapists and rheumatologists who seek to improve these properties in these patients, this study aims provide a new type of disease management.
\end{abstract}

\section{Key words}

Vibration, Pain, Fibromyalgia, Strength, Balance

\section{Introduction}

Fibromyalgia (FM) is a rheumatological syndrome of unknown aetiology. FM is characterized by widespread noninflammatory musculoskeletal pain present for at least 3 months and an acute response to digital palpation with $4 \mathrm{~kg} / \mathrm{cm}^{2}$ of pressure in at least 11 out of 18 tender points ${ }^{[1]}$. It is generally accompanied by sleep disturbances, stiffness, fatigue, depression, and anxiety. For treatment of pain associated with FM, several therapies have been used including 
pharmacologic interventions with antidepressants, non-steroidal anti-inflammatory drugs, sedatives, muscle relaxants and opiates ${ }^{[2]}$ and non-pharmacologic therapies such as Tai Chi, yoga, low impact aerobics, walking, water aerobics and whole-body vibration (WBV) ${ }^{[3-6]}$. WBV is a mode of exercise that has recently been utilized for its positive effects on pain, balance, and neural, muscular and skeletal systems in different patient populations ${ }^{[7-9]}$.

WBV has been used to reduce chronic pain in several patient ${ }^{[10,11]}$, including $\mathrm{FM}^{[12]}$. It is not clear how vibration therapies lead to reductions in pain. One possible explanation is that vibrations activate skin somatic sensory receptors, thereby masking pressure and touch processes. According to the gate control hypothesis ${ }^{[13]}$, subsequently modified by Kerr ${ }^{[14]}$, the vibrations can mask pain in a fashion similar to transcutaneous electrical nerve stimulation (TENS) ${ }^{[15]}$.

Muscle strength depends on both the cross-sectional area of the muscle and on neural activity. The cross-sectional area of the quadriceps femoris muscle is within the normal range in persons with $\mathrm{FM}^{[16,17]}$; however, several studies have found that women with FM have significantly lower isometric and isokinetic strength in the quadriceps femoris than healthy individuals ${ }^{[18-20]}$. Reduced maximal muscle strength of knee extensors in FM has been associated with poor outcomes in functional tests related to daily living activities (sitting up and down on a chair, walking and ladder climbing) ${ }^{[21]}$, this suggests that there is a defect in neural activity in muscles of FM patients. In WBV, the first adaptation affects neurological mechanisms and is independent of increased muscle mass. There are several possible explanations for the beneficial effects of WBV on muscle function in FM, including increased motor unit synchronization, co-contraction of synergistic muscles, increased inhibition of antagonistic muscles, and a repetitive muscle motion leading to a large boost in musculoskeletal structures due to changes in muscle stiffness in response to the vibration ${ }^{[22]}$. The decline of knee extensor strength in FM has been associated with gait disorders and pain, and may also contribute to balance problems. This is an important disease mechanism since balance problems are the sixth most frequent symptom in FM, affecting $45 \%$ of patients ${ }^{[23]}$. Patients with FM have impaired balance ${ }^{[24,25]}$, increased risk of falling ${ }^{[26]}$, and gait problems ${ }^{[27]}$.

Patients with chronic pain disorders like FM have associated structural changes in the central nervous system (CNS), including parts of the somatosensory and motor systems ${ }^{[28]}$. The somatosensory system is an integral component of the motor control system that facilitates the recognition of location and experience of peripheral stimuli and body position. In chronic pain, this system may be disrupted by alterations in peripheral and cortical processing, and FM patients with chronic pain typically describe diverse alterations of the somatosensory system ${ }^{[29]}$.

Balance is a complex process that involves the reception and integration of sensory stimuli from three systems (somatosensory, vestibular and visual). When the visual system offers limited references, the development of balance is dependent on the other two systems. Previous studies reported the effects of visual aids on balance ${ }^{[29]}$, but there is a lack of knowledge about the effects of reciprocal WBV on balance without vision in FM patients.

The effects of WBV on patients with FM was previously studied using vertical platforms, but the effects of WBV using a tilt platform with reciprocal vertical displacement on the left and right side of the fulcrum on pain, strength and the somatosensory system in FM have not studied. The purpose of this study was to investigate the effects of 3 weekly sessions of tilting WBV (6 repetitions of 45-60 seconds at $12.5 \mathrm{~Hz}$ ), over a 12 week period, on pain, strength and the somatosensory system in FM patients.

\section{Material and methods}

\subsection{Participants recruitment}

The population comprised women who participated in a local FM association. The women were eligible if FM had been diagnosed by a rheumatologist in accordance with the diagnostic criteria of the American College of Rheumatology (ACR) ${ }^{[13]}$. Several exclusion criteria were applied: history of severe trauma, frequent migraines, peripheral nerve entrapment, inflammatory rheumatic diseases, severe psychiatric illness, other diseases that prevent physical loading, 
pregnancy, participation in another psychological or physical therapy program, and participation in regular physical exercise more than once a week for 30 minutes or longer during a 2-week period in the last 5 years.

A total of 60 potentially eligible participants responded and requested additional information (see Figure 1), but 19 of those candidates were subsequently excluded: three had participated in other therapies (massages and psychological treatment) that could potentially interact with the current intervention, ten had other severe diseases and did not meet the inclusion criteria, and six lived too far from the intervention setting. After the study protocol was explained, the 41 remaining female patients aged 41 to 65 years old gave their written informed consent to participate according to the updated Declaration of Helsinki. The project protocol was approved by the Biomedical Ethical Committee of the University of Extremadura.

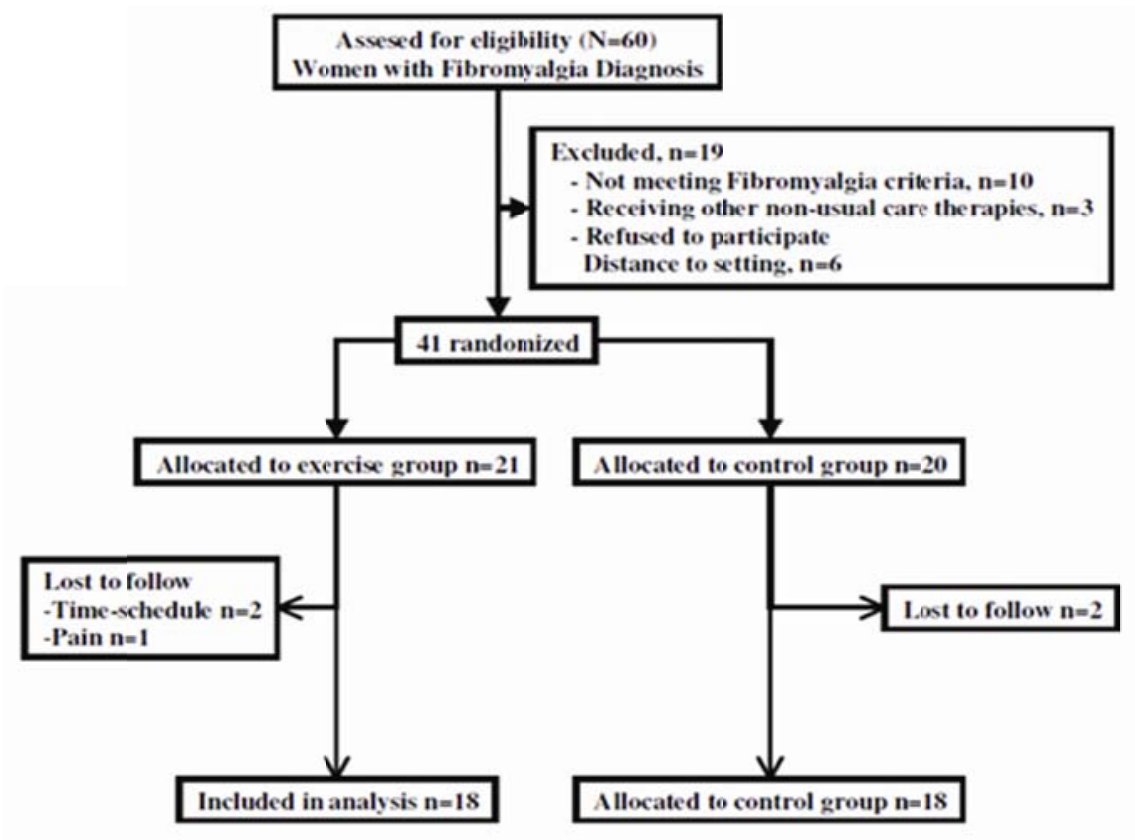

Figure 1. Flow Diagram of Participants

\subsection{Design}

We conducted a blinded randomized controlled trial (ISRCTN16950947). The participants were randomly assigned to either the vibration group $(n=21)$ or the control group $(n=20)$ by a research assistant using a random number table. Each participant was assigned a code number. Other members of the research team, who were blinded to the group assignment of each participant, conducted the study measurements. Additional members of the research team applied the intervention, and other team members performed the statistical analyses.

\subsection{I ntervention}

All the participants received standard care that included medical attention through the public health system (hospital and outpatient clinic, including primary care) and social support through the local FM association. Patients in the vibration group had a 30-minute instruction session on how to self-administer the 36 vibration sessions with the reciprocating Galileo Fitness Platform (Novotec Medical GmbH, Pforzheim, Germany), which oscillates through the medial axis, in contrast to other oscillating commercial platforms that oscillate uniformly up and down.

The intervention consisted of 3 sessions per week over a 12-week period. Each session included a 10-minute warm-up of slow walking and easy movements, and then 6 repetitions of WBV with a frequency of $12.5 \mathrm{~Hz}$, with a 60 second rest interval between repetitions. The duration of each repetition was 30 seconds during the first month, 45 seconds during the 
second month, and 60 seconds during the third month. The stance of the participants on the platform alternated_between stance $\mathrm{A}$ and stance $\mathrm{B}$ for each repetition:

Stance A: Begin with the feet planted perpendicular to the midline axis of the platform with the right foot placed slightly ahead of the left foot. Lift the toes of the right foot and the heel of the left foot $4 \mathrm{~mm}$ above the surface of the platform. Bend the knees and maintain a 45-degree knee angle. Keep the back and head straight.

Stance B: Begin with the feet planted perpendicular to the midline axis of the platform with the left foot placed slightly ahead of the right foot. Lift the toes of the left foot and the heel of the right foot $4 \mathrm{~mm}$ above the surface of the platform. Bend the knees and maintain a 45-degree knee angle. Keep the back and head straight.

Each participant was required to sign and date a notebook after completing each vibration session. A research assistant also spoke to each participant once a week during a 3-minute phone conversation in order to check progression through the program, provide instructions, and give emotional support. During the 3-month study period, the participants of the control group continued their daily activities, which did not include any form of physical exercise similar to the exercises performed by the participants of the vibration group. The vibration program was implemented at the local FM association, and the measurements were performed at the Fitness and Quality of Life Laboratory at the University of Extremadura (Spain).

\subsection{Outcome measures}

\subsubsection{Pain}

Pain was assessed by measuring the pressure at which participants felt pain at each of 18 tender points according to ACR criteria ${ }^{[1]}$. Pain was measured by the same trained person for each participant, using a Wagner FDIX ${ }^{\text {TM }}$ Digital Algometer (Wagner, USA). The sum of the threshold pressure at all tender points was calculated. The pain threshold at each tender point was determined by applying increasing pressure with the algometer perpendicular to the tissue, at a rate $1 \mathrm{Kg} / \mathrm{s}$. Patients were asked to say "STOP" at the moment pressure became painful. The mean of two successive measurements at each tender point was used for the analysis. Tender points were scored as positive when the patient noted pain at a pressure of $4 \mathrm{~kg} / \mathrm{cm}^{2}$ or less.

A 7-day reliability test was conducted with 10 participants in our laboratory; the smallest real difference was $14.9 \%$ for widespread pain and $15.2 \%$ for knee pain.

\subsubsection{Strength}

Isometric, concentric and eccentric knee strength (flexion and extension) was always measured by the same trained person, using an isokinetic dynamometer (Biodex System 3). A 7-day reliability test was previously conducted in our laboratory ${ }^{[30]}$.

\subsubsection{Somatosensory system}

The somatosensory system was evaluated using a stabilometry platform, the Biodex Balance System (BBS; Biodex, USA). This instrument measures 3 indices: the medial-lateral stability index (MLSI), the anterior-posterior stability index (APSI) and the overall stability index (OSI), which is a composite of the MLSI and APSI ${ }^{[31]}$. The patients are evaluated with both feet on the platform, with the dominant leg on the platform and with the non-dominant leg on the platform, and all the trials were performed with closed eyes. The duration in seconds ${ }^{[32]}$ or the number of trials required to complete 30 seconds were recorded ${ }^{[33]}$. A 7-day reliability test was performed with 10 participants in our laboratory: the smallest real difference for OSI was $19.6 \%$ with both feet on the platform, $27.8 \%$ with the dominant leg and $31.2 \%$ with the non-dominant leg; and the smallest real difference for APSI was $18.7 \%$ with both feet on the platform, $26.3 \%$ with the dominant leg and $30.6 \%$ with the non-dominant leg. 


\subsection{Data analysis}

A 7-day reliability study on pain and balance tests was conducted with 10 participants before the start of the study. The relative reliability was determined with Intraclass Correlation Coefficient (ICC) $)_{1,1}$ in two sessions ${ }^{[34]}$. The absolute reliability was determined with the SEM $[\mathrm{SEM}=\mathrm{SD} \sqrt{ }((1-\mathrm{ICC})$, where $\mathrm{SD}$ is the average SD of day 1 and day 2 , and the real minimum change $(1.96 \times \sqrt{ } 2 \times \mathrm{SEM})]^{[35]}$.

Mean and standard deviation (SD) are given as descriptive statistics. Baseline characteristics were compared using Student's $t$-test for independent samples and the distribution of data was examined by Kolmogorov-Smirnov, with Lilliefors significance correction. Since the pre- and post-test measures are paired measures from the same subjects, we used the ANOVA for repeated measures.

Results were considered statistically significant when the significance values, $p$, were $<.05$. In addition to the $p$ values, we provided detailed statistics including the mean and $95 \%$ confidence interval for better depicting the change within each group from baseline to 3 months, and the treatment effect. If the null value of the comparative measure, the mean, lies inside the confidence interval then the result is not statistically significant. These additional statistics are recommended for biomedical journals ${ }^{[36]}$ for helping readers to determine the size of differences and to compare results with other studies. The differences between post- and pre-test were used to describe the changes from baseline to 3 months, and the differences between groups in the change from baseline to 3 months were used to estimate the treatment effect. The mean and $95 \%$ confidence intervals of changes were calculated using Student's $t$-test for independent samples. In order to be useful to a wider spectrum of readers, we performed an efficacy analysis including persons who completed the intervention to study the specific effects of the protocol, and we also reported an intent-to-treat analysis. Cohen's coefficient was used to assess the change. A change of 0-0.2 was considered very small, a change of 0.2-0.6 was considered small, a change of 0.6-1.2 was considered moderate, a change of 1.2-2 was considered large and a change $>2.0$ was considered very large ${ }^{[37]}$.

All analyses were performed with SPSS software, version 16.0.

Table 1. Characteristics of Women with Fibromyalgia Who Followed the Whole body Vibration Exercise Program and Controls* $(\mathrm{n}=36)$

\begin{tabular}{|c|c|c|c|}
\hline Group & Control (n = 18) (Mean \pm SD) & Exercise $(n=18)($ Mean \pm SD) & $p$ \\
\hline Age (y) & $53.0(12.0)$ & $52.4(10.8)$ & .860 \\
\hline Weight (kg) & $70.0(10.5)$ & $73.3(14.4)$ & .384 \\
\hline Height (cm) & $156.0(4.7)$ & $156.4(5)$ & .782 \\
\hline Number of tender points $(1-18)$ & $15(5)$ & $15(4)$ & .943 \\
\hline Duration of symptoms (years) & $13.7(6.2)$ & $12.7(6.7)$ & .672 \\
\hline FIQ total score (points) & $53.6(12.3)$ & $59.2(9.7)$ & .681 \\
\hline Isometric knee extension strength $(\mathrm{Nm})$ & $79.4(25.9)$ & $74.3(28.7)$ & .585 \\
\hline Isometric knee flexion strength $(\mathrm{Nm})$ & $28.0(12.3)$ & $24.8(10.5)$ & .407 \\
\hline $\operatorname{SP} 18 \mathrm{TP}\left(\mathrm{Kg} / \mathrm{cm}^{2}\right)$ & $20.3(7.8)$ & $17.9(6.8)$ & .959 \\
\hline \multicolumn{4}{|l|}{2 leg eyes-closed } \\
\hline Overall SI $\left({ }^{\circ}\right)$ & $2.3(1.0)$ & $2.0(1.2)$ & .368 \\
\hline Anterior-Posterior SI $\left({ }^{\circ}\right)$ & $1.5(0.7)$ & $1.4(0.8)$ & .543 \\
\hline Middle-Lateral SI $\left(^{\circ}\right)$ & $1.4(0.9)$ & $1.1(0.9)$ & .332 \\
\hline \multicolumn{4}{|l|}{ Single dominant leg eyes-closed } \\
\hline Overall SI $\left(^{\circ}\right)$ & $2.7(0.7)$ & $2.9(0.7)$ & .583 \\
\hline Anterior-Posterior SI $\left({ }^{\circ}\right)$ & $1.8(0.6)$ & $2.2(0.7)$ & .253 \\
\hline Middle-Lateral SI $\left({ }^{\circ}\right)$ & $1.5(0.5)$ & $1.4(0.4)$ & .552 \\
\hline \multicolumn{4}{|l|}{ Single no dominant leg eyes-closed } \\
\hline Overall SI $\left({ }^{\circ}\right)$ & $3.1(1.1)$ & $2.7(0.8)$ & .297 \\
\hline Anterior-Posterior SI $\left(^{\circ}\right)$ & $2.3(1.2)$ & $2.0(0.8)$ & .461 \\
\hline Middle-Lateral SI $\left({ }^{\circ}\right)$ & $1.7(0.5)$ & $1.5(0.4)$ & .578 \\
\hline
\end{tabular}

*Values expressed as mean (SD); FIQ total score, Fibromyalgia Impact Questionnaire total score 
Table 2. Effects of 3-month Whole Body Vibration Program in Fibromyalgia $(\mathrm{n}=36)$. Efficacy Analysis

\begin{tabular}{|c|c|c|c|c|c|c|c|}
\hline \multirow[b]{2}{*}{ Outcome measure } & \multicolumn{2}{|c|}{ Baseline } & \multicolumn{2}{|c|}{ Post-treatment } & \multirow{2}{*}{$\begin{array}{l}\text { Treatment effect } \\
\text { Mean }(95 \% \mathrm{CI})\end{array}$} & \multirow[b]{2}{*}{$p \dagger$} & \multirow{2}{*}{$\begin{array}{l}\text { Effect } \\
\text { size }\end{array}$} \\
\hline & $\begin{array}{l}\text { Control (n = 18) } \\
\text { Mean (SD) }\end{array}$ & $\begin{array}{l}\text { Exercise }(n=18) \\
\text { Mean (SD) }\end{array}$ & $\begin{array}{l}\text { Control (n = 18) } \\
\text { Mean (SD) }\end{array}$ & $\begin{array}{l}\text { Exercise }(n=18) \\
\text { Mean (SD) }\end{array}$ & & & \\
\hline $\begin{array}{l}\text { Isometric knee extension } \\
\text { strength }(\mathrm{Nm})\end{array}$ & $79.42(25.93)$ & $81.66(33.13)$ & $77.81(24.70)$ & $90.21(33.28)$ & $10.16(0.16$ to 20.15$)$ & .047 & 0.50 \\
\hline $\begin{array}{l}\text { Isometric knee flexion } \\
\text { strength }(\mathrm{Nm})\end{array}$ & $28.07(12.30)$ & $24.16(9.86)$ & $26.63(9.58)$ & $27.92(11.43)$ & 4.58 (0.64 to 9.74$)$ & .025 & 0.36 \\
\hline $\begin{array}{l}\text { Concentric knee } \\
\text { extension strength (Nm) }\end{array}$ & $61.97(23.02)$ & $58.78(21.85)$ & $66.80(24.39)$ & $75.28(19.93)$ & 11.68 (1.64 to 21.70$)$ & .024 & 0.82 \\
\hline $\begin{array}{l}\text { Concentric knee flexion } \\
\text { strength }(\mathrm{Nm})\end{array}$ & $25.86(9.97)$ & $21.72(6.86)$ & $26.61(9.43)$ & $27.94(8.84)$ & $5.47(2.01$ to 8.93$)$ & .003 & 1.11 \\
\hline $\begin{array}{l}\text { Eccentric Knee flexion } \\
\text { strength }(\mathrm{Nm})\end{array}$ & $112.68(35.42)$ & $90.34(31.01)$ & $109.53(37.73)$ & $106.24(32.87)$ & 19.05 (-0.23 to 38.34$)$ & .050 & 0.46 \\
\hline Knee R + Knee L (Kgf) & $3.09(1.87)$ & $2.08(1.02)$ & $2.26(1.11)$ & $2.28(1.18)$ & $1.03(0.12$ to 1.94$)$ & .028 & 0.51 \\
\hline Algometer Score (Kgf) & $20.37(7.82)$ & $17.90(6.88)$ & $17.58(6.63)$ & $19.61(7.52)$ & 4.51 (1.31 to 7.69$)$ & .007 & 0.24 \\
\hline \multicolumn{8}{|l|}{2 leg eyes-closed } \\
\hline Overall SI $\left(^{\circ}\right)$ & $2.37(1.08)$ & $2.02(1.20)$ & $2.25(1.21)$ & $1.14(0.70)$ & $-0.75(-1.40$ to -0.10$)$ & .023 & -0.78 \\
\hline Anterior-Posterior SI $\left({ }^{\circ}\right)$ & $1.57(0.71)$ & $1.41(0.84)$ & $1.52(0.83)$ & $0.76(0.37)$ & $-0.14(-1.13$ to -0.05$)$ & .031 & -0.75 \\
\hline Middle-Lateral SI $\left(^{\circ}\right)$ & $1.48(0.59)$ & $1.17(0.90)$ & $1.37(0.87)$ & $0.71(0.65)$ & $-0.75(-1.19$ to -0.30$)$ & .113 & -1.23 \\
\hline \multicolumn{8}{|l|}{$\begin{array}{l}\text { Single dominant leg } \\
\text { eyes-closed }\end{array}$} \\
\hline Overall SI $\left({ }^{\circ}\right)$ & $2.74(0.80)$ & $2.90(0.76)$ & $2.86(0.82)$ & $1.54(0.68)$ & $-1.48(-2.24$ to -0.73$)$ & $\begin{array}{l}<.00 \\
1\end{array}$ & -1.45 \\
\hline Anterior-Posterior SI $\left({ }^{\circ}\right)$ & $1.88(0.68)$ & $2.20(0.79)$ & $1.93(0.91)$ & $1.10(0.59)$ & $-1.56(-1.91$ to -0.37$)$ & .005 & -1.09 \\
\hline Middle-Lateral SI $\left({ }^{\circ}\right)$ & $1.56(0.53)$ & $1.45(0.40)$ & $1.67(0.60)$ & $0.82(0.32)$ & $-0.75(-1.19$ to -0.30$)$ & .002 & -1.23 \\
\hline \multicolumn{8}{|l|}{$\begin{array}{l}\text { Single no dominant leg } \\
\text { eyes-closed }\end{array}$} \\
\hline Overall SI $\left({ }^{\circ}\right)$ & $3.17(1.19)$ & $2.77(0.80)$ & $2.85(0.80)$ & $1.62(0.79)$ & $-0.81(-1.66$ to 0.01$)$ & .049 & -0.73 \\
\hline Anterior-Posterior SI $\left({ }^{\circ}\right)$ & $2.30(1.21)$ & $2.01(0.89)$ & $2.17(0.77)$ & $0.99(0.50)$ & $-8.89(-1.74$ to -0.03$)$ & .040 & -0.77 \\
\hline Middle-Lateral SI $\left({ }^{\circ}\right)$ & $1.73(0.53)$ & $1.50(0.48)$ & $1.44(0.48)$ & $1.06(0.56)$ & $-0.27(-0.78$ to 0.22$)$ & .500 & -0.40 \\
\hline
\end{tabular}

Table 3. Effects of 3-month Whole Body Vibration program in fibromyalgia $(\mathrm{n}=41)$. Intent-to-treat analysis.

\begin{tabular}{|c|c|c|c|c|c|c|c|}
\hline \multirow[b]{2}{*}{ Outcome measure } & \multicolumn{2}{|c|}{ Baseline } & \multicolumn{2}{|c|}{ Post-treatment } & \multirow{2}{*}{$\begin{array}{l}\text { Treatment effect } \\
\text { Mean }(95 \% \mathrm{CI})\end{array}$} & \multirow[b]{2}{*}{$p \dagger$} & \multirow{2}{*}{$\begin{array}{l}\text { Effect } \\
\text { size }\end{array}$} \\
\hline & $\begin{array}{l}\text { control }(n=20) \\
\text { Mean (SD) }\end{array}$ & $\begin{array}{l}\text { exercise }(n=21) \\
\text { Mean (SD) }\end{array}$ & $\begin{array}{l}\text { control }(n=20) \\
\text { Mean (SD) }\end{array}$ & $\begin{array}{l}\text { exercise }(n=21) \\
\text { Mean (SD) }\end{array}$ & & & \\
\hline $\begin{array}{l}\text { Isometric knee } \\
\text { extension strength }(\mathrm{Nm})\end{array}$ & $79.28(25.73)$ & 80.14 (34.15) & 77.68 (24.58) & $87.28(34.89)$ & $8.13(-0.11$ to 17.59$)$ & .053 & 0.62 \\
\hline $\begin{array}{l}\text { Isometric knee flexion } \\
\text { strength }(\mathrm{Nm})\end{array}$ & $27.53(12.25)$ & $25.93(10.02)$ & $26.33(9.74)$ & $29.26(11.01)$ & $4.52(0.56$ to 8.49$)$ & .026 & 0.34 \\
\hline $\begin{array}{l}\text { Concentric knee } \\
\text { extension strength }(\mathrm{Nm})\end{array}$ & $61.21(22.32)$ & $58.51(22.29)$ & $65.44(23.86)$ & $72.34(21.83)$ & $9.6(0.45$ to 18.75$)$ & .040 & 0.68 \\
\hline $\begin{array}{l}\text { Concentric knee flexion } \\
\text { strength }(\mathrm{Nm})\end{array}$ & $24.67(10.17)$ & $22.48(6.57)$ & $25.40(9.70)$ & $27.84(8.12)$ & $4.63(1.51$ to 7.75$)$ & .005 & 0.64 \\
\hline $\begin{array}{l}\text { Eccentric Knee flexion } \\
\text { strength }(\mathrm{Nm})\end{array}$ & $111.25(34.01)$ & $95.79(31.73)$ & $108.08(36.18)$ & $108.67(31.18)$ & $16.05(-0.89$ to33.01 ) & .063 & .0 .62 \\
\hline Knee R + Knee L & $28.74(18.84)$ & $2.30(1.16)$ & $2.10(1.12)$ & $2.35(1.19)$ & $0.81(8.09$ to66.00 $)$ & .047 & 0.66 \\
\hline Algometer Score (Kgf) & $19.82(7.64)$ & $19.58(7.47)$ & $17.00(6.58)$ & $20.46(71.86)$ & $3.70(0.09$ to 16.22$)$ & .014 & 0.83 \\
\hline \multicolumn{8}{|l|}{2 leg eyes-closed } \\
\hline Overall SI $\left({ }^{\circ}\right)$ & $2,48(1.04)$ & $2.20(1.28)$ & $2.20(1.15)$ & $1.43(1.07)$ & $-0.76(-1.40$ to 1.10$)$ & .024 & -0.67 \\
\hline Anterior-Posterior SI $\left({ }^{\circ}\right)$ & $1.58(0.71)$ & $1.47(0.83)$ & $1.53(0.82)$ & $0.91(0.95)$ & $-0.97(-1.66$ to -0.28$)$ & .037 & -0.07 \\
\hline Middle -Lateral SI $\left(^{\circ}\right)$ & $1.61(1.07)$ & $1.35(0.99)$ & $1.51(1.01)$ & $0.93(0.89)$ & $-0.31(-0.71$ to 0.08$)$ & .118 & -0.50 \\
\hline \multicolumn{8}{|l|}{$\begin{array}{l}\text { Single dominant leg } \\
\text { eyes-closed }\end{array}$} \\
\hline Overall SI $\left({ }^{\circ}\right)$ & $2.79(0.80)$ & $2.96(0.75)$ & $2.91(0.81)$ & $1.81(0.95)$ & $-0.70(-1.96$ to -0.56$)$ & $<.001$ & -1 \\
\hline Anterior-Posterior SI $\left({ }^{\circ}\right)$ & $2.03(0.77)$ & $2.31(0.81)$ & $2.08(0.96)$ & $1.38(0.91)$ & $-0.97(-1.66$ to -0.28$)$ & .007 & -0.88 \\
\hline Middle -Lateral SI $\left({ }^{\circ}\right)$ & $1.64(0.55)$ & $1.46(0.42)$ & $1.76(0.61)$ & $0.93(0.45)$ & $-0.63(-1.03$ to -0.23$)$ & .003 & -0.71 \\
\hline \multicolumn{8}{|l|}{$\begin{array}{l}\text { Single no dominant leg } \\
\text { eyes-closed }\end{array}$} \\
\hline Overall SI $\left({ }^{\circ}\right)$ & $3.06(1.16)$ & $2.84(0.84)$ & $2.73(0.83)$ & $1.82(0.89)$ & $-0.70(-1.42$ to 0.02$)$ & .050 & -0.66 \\
\hline Anterior-Posterior SI $\left({ }^{\circ}\right)$ & $2.26(1.13)$ & $2.11(0.90)$ & $2.13(0.73)$ & $1.21(0.74)$ & $-0,77(-1.51$ to -0.03$)$ & .041 & -0.21 \\
\hline Middle -Lateral SI $\left(^{\circ}\right)$ & $1.72(0.49)$ & $1.46(0.46)$ & $1.44(0.44)$ & $1.05(0.53)$ & $-0.12(-0.50$ to 0.26$)$ & .517 & -0.22 \\
\hline
\end{tabular}

*Values expressed as mean (SD); $p+\mathrm{p}$ values from ANOVA for repeated measures adjusted by baseline data to compare different between groups after 3-month Whole Body Vibration program in fibromyalgia .intent-to-treat analysis. 


\section{Results}

The participant characteristics for this study are summarized in Table 1. The control and experimental group were comparable with respect to all variables at baseline.

In efficacy analysis (see Table 2$)$, the treatment effect on widespread pain was an improvement of $23.5 \%(P<.05)$ and on knee pain, an improvement of $40 \%(P<.05)$.

In the efficacy analysis (see Table 2), treatment resulted in an improved strength of greater than $19 \%(P<.05)$ in concentric knee extension and flexion. The treatment effect on balance with eyes closed was an improvement in OSI of greater than $25 \%(P<.05)$ and in APSI of greater than $40 \%(P<.05)$ in all positions evaluated.

In the intent to treat (ITT) analysis (see Table 3), the treatment effect was a $20 \%$ improvement in widespread pain $(\mathrm{P}<.05)$ and a $31 \%$ improvement in knee pain $(P<.05)$. The treatment effect on strength was an improvement in concentric knee extension and flexion of greater than $15 \%(P<.05$; see Table 3$)$. The treatment effect on balance with eyes closed was an improvement in OSI of greater than 20\% $(P<.05)$ and in APSI of greater than $35 \%(P<.05)$ in all positions evaluated

\section{Discussion}

Previous studies reported the feasibility and effectiveness of WBV in FM patients ${ }^{[12,38]}$, including the effects of the WBV program used in the present study on health related quality of life and dynamic balance with visual feedback ${ }^{[6,39]}$. The present study showed that WBV also has beneficial effects on widespread pain, the somatosensory system and muscular strength (isometric, concentric and eccentric knee contractions). Our results allow a more detailed study of the mechanism of adaptation to tilting WBV in FM.

The current vibration program could serve as an additional resource for patients with FM that can easily be implemented in different settings (e.g. primary care, FM associations, clinics or gyms.) because the program can be readily selfadministered in one small room after an initial instruction session. This is a particular advantage for patients living in socio-demographic areas lacking key resources such as gyms, warm-water pools, clinics or highly specialized FM technicians ${ }^{[40,41]}$. Only one participant dropped out of the program $(5.5 \%)$ and this was due to pain in the legs. The remaining participants completed the program without secondary adverse effects $(94.5 \%)$; this is an important outcome since $94.5 \%$ this is an important outcome since our adherence rate is substantially higher than that reported for other intervention studies with FM patients ${ }^{[42,43]}$.

Previous studies have reported beneficial effects of WBV in a variety of populations, for example, the elderly ${ }^{[9,44-46]}$, untrained females ${ }^{[47,48]}$ postmenopausal women ${ }^{[49,50]}$, Parkinson's disease ${ }^{[51-53]}$, multiple sclerosis ${ }^{[54]}$ and stroke ${ }^{[55-57]}$.

Previous studies suggest that the traditional exercise program alone has no effect on pain in patients with FM ${ }^{[12,41,58]}$. Water therapy has been identified as an important therapy for pain in FM. Balneotherapy and dry-land training both deliver improvements in pain such as a reduction in the number of tender points ${ }^{[59,60]}$. Eight weeks of training with 5 different sessions per week (including one water session) led to a $40 \%$ improvement in body pain measured by the questionnaire Short Form $36^{[41]}$. Jentoft et al. ${ }^{[61]}$ detected reductions in pain after 2 sessions per week in a heated pool for 20 weeks, while Gusi et al. ${ }^{[62]}$ found that three sessions per week in warm water decreased pain measured on VAS (29\%) and pain/discomfort item of the EQ-5D (16\%). Mannerkorpi et al. ${ }^{[63]}$ achieved a $15 \%$ reduction in pain with one pool-based session per week over a 6 month period. WBV is a new therapeutic approach and to our knowledge the study by Alentorn-Geli et al. ${ }^{[12]}$ is the only one study to investigate the effect of WBV on FM-related pain; these authors propose exercise plus supplementary vertical WBV as an effective approach for improving pain in FM. Our study used an intervention exclusively based on tilting WBV therapy and achieved a positive effect on pain relief measured by a digital algometer, indicating that WBV therapy alone can be effective in treating the most important symptoms of FM. In turn, this novel therapeutic approach may have beneficial effects on quality of life, physical functioning and health status in FM 
patients. An inherent problem in pain assessment is the subjective nature of the measurement, and many studies utilize the VAS scale or manual palpation, but these methods do not account for individual differences in pain perception. We aimed to avoid this problem by assessing pain with a digital algometer, which is a quantitative tool for assessment of pain commonly used in clinical practice ${ }^{[64]}$. We measured pain over the whole body, but also focused specifically on the knees, which predominantly absorb the impacts transmitted by the platform.

Vibration strongly affects the afferent discharge from fast adapting mechanoreceptors and muscle spindles, and this is a likely mechanism to reduce the perception of pain. In addition to its effects on pain, we believe this process is related to improvement in balance because the gastrocnemius muscle is the agonist for control of forward postural sway, and the anterior tibialis muscle is the agonist for control of backward postural sway.

Patients with FM are deconditioned compared with normal subjects, with a reduction in maximal voluntary isokinetic strength in the quadriceps muscle that is thought to result from a primary muscle dysfunction ${ }^{[65]}$. FM patients with many tender points have a significant reduction $(45 \%)$ in peak torque isokinetic knee extension and flexion. Possible mechanisms for this reduced muscle function include pain, negative feedback on motor unit recruitment, peripheral neurogenic problems and lack of motivation ${ }^{[65]}$. The increase in voluntary peak torque isokinetic strength $(19 \%)$ in our study is probably due to the observed improvements in pain at tender points, allowing an improvement in the feedback to motor units, together with increased motivation to develop strength and to improve functions related to daily living (stair climbing, walking or sitting up and down on a chair).

Some studies using land-based resistance training have shown that exercise is effective for improving strength in $\mathrm{FM}^{[66,67]}$, while Gusi et al. ${ }^{[62]}$ have shown that warm water therapy improves knee extensor and flexor strength for concentric actions at slow speed. In our study, we obtained similar results using self-administered therapy.

Balance problems are one of the 10 most debilitating symptoms of FM and occur in $45 \%-68 \%$ of patients ${ }^{[68]}$. We propose that several factors contribute to balance problems in FM patients including vision problems, vestibular problems and changes in somatosensory impulses for pain ${ }^{[28]}$. The somatosensory response is dependent on specific clinical and other factors such as reduction in muscle strength, and sensory or motor deficits ${ }^{[69]}$, and is also altered in $\mathrm{FM}^{[70]}$.

The first sensory inputs used in automatic postural control and postural orientation are the somatosensory input from muscle spindles, Golgi tendons, and superficial and deep cutaneous afferent nerves ${ }^{[71]}$. However, proper balance also requires rapid and automatic corrections from the CNS. FM patients have abnormal perception of pain and slight somatosensory stimulation, and since our proposed therapy stimulates the CNS and may enhance activation of the somatosensory system, this may contribute to better postural control in FM patients.

The positive effect of WBV on the somatosensory system in patients with FM is a novel and important finding. This new technology has great potential to improve the quality of life in patients with pain and could help to clarify the specific mechanisms and adaptations of the somatosensory system, especially in FM patients.

Other authors have reported improvements in balance in FM when balance was measured with the eyes open. These improvements are likely due to training of the somatosensory system and to effects of vision ${ }^{[6]}$. In our study, the improvements in balance occurred independent of visual inputs, suggesting that the therapy improves balance through stimulation of the somatosensory system.

We propose that interventions that combine balance training with exercise and vibratory exercise may be effective in improving balance and somatosensory function in FM.

\section{Limitations}

This study has several limitations. We relied on self-administration of the vibratory therapy, including auto-adjustment of the knee angles, and cannot be certain that each participant administered the therapy exactly as explained to them at the Published by Sciedu Press 
start of the study. Only participants in the experimental group received weekly telephone calls during the WBV program. The social contact and support provided by these calls may have improved the motivation of this group in contrast to the control group, which did not receive the calls. In addition, members of the exercise group did a 10-minute warm-up of slow walking, so we cannot confirm that the observed improvements were solely due to WBV. The balance test was performed with eyes closed, thereby excluding effects of vision, and in this situation balance is maintained through the vestibule and the somatosensory system. Therefore, we cannot determine whether the improvements achieved were due solely to improvements in the somatosensory system or whether the vestibular system was also involved. In the current study we evaluated the effects of WBV on balance with closed eyes, and in future studies it will be important to control for medications used by the participants that may have an influence on postural control.

Further studies will be necessary to determine the optimal amount of WBV therapy and its relationship to the level of disability in FM. It will also be important to compare the effects of WBV therapy on anterior-posterior and middle-lateral balance using different postures on titling, vertical and stochastic platforms. Finally, a thorough assessment of the cost-effectiveness and cost-utility of WBV treatments is needed in order to ensure that this therapy can be provided to large populations of patients suffering from FM.

\section{Conclusions}

Twelve weeks of tilting whole body vibration therapy 3 times a week, with a frequency of $12.5 \mathrm{~Hz}$, had a positive effect on muscle strength, the somatosensory system and pain in women with fibromyalgia. This study supports the development of novel approaches to physical therapy programs that utilize vibration therapy.

\section{Ethics Committees approval}

Approved by the Biomedical Ethics Committee of the University of Extremadura on 12/06/2005; reference number 11/05 (academic research funded in 2007). All participants gave their written informed consent to participate according to the updated Declaration of Helsinki, and the project protocol was approved by the Biomedical Ethics Committee of the University of Extremadura.

\section{Acknowledgements}

We thank the study participants and Désirée Möller for preserving blinded data and administrative tasks.

\section{Competing interests}

The authors declare they have no competing interests

\section{References}

[1] Wolfe F, Smythe HA, Yunus MB, Bennett RM, Bombardier C, Goldenberg DL, et al. The American College of Rheumatology 1990 Criteria for the Classification of Fibromyalgia. Report of the Multicenter Criteria Committee. Arthritis Rheum. 1990 Feb; 33(2): 160-72. PMid:2306288 http://dx.doi.org/10.1002/art.1780330203

[2] Rao SG, Bennett RM. Pharmacological therapies in fibromyalgia. Best practice \& research. 2003 Aug; 17(4): 611-27.

[3] Goldenberg DL, Burckhardt C, Crofford L. Management of fibromyalgia syndrome. JAMA. 2004 Nov 17; 292 (19): $2388-95$. PMid:15547167 http://dx.doi.org/10.1001/jama.292.19.2388

[4] Silver DS, Wallace DJ. The management of fibromyalgia-associated syndromes. Rheum Dis Clin North Am. 2002 May; 28(2): 405-17. http://dx.doi.org/10.1016/S0889-857X(02)00003-0

[5] Mannerkorpi K, Iversen MD. Physical exercise in fibromyalgia and related syndromes. Best practice \& research. 2003 Aug; 17(4): 629-47.

[6] Gusi N, Parraca JA, Olivares PR, Leal A, Adsuar JC. Tilt vibratory exercise and the dynamic balance in fibromyalgia: A randomized controlled trial. Arthritis Care Res (Hoboken). 2010 Aug; 62(8): 1072-8. PMid:20235191

http://dx.doi.org/10.1002/acr.20180 
[7] Rees SS, Murphy AJ, Watsford ML. Effects of whole body vibration on postural steadiness in an older population. Journal of science and medicine in sport / Sports Medicine Australia. 2009 Jul; 12(4): 440-4.

[8] Torvinen S, Kannus P, Sievanen H, Jarvinen TA, Pasanen M, Kontulainen S, et al. Effect of four-month vertical whole body vibration on performance and balance. Medicine and science in sports and exercise. 2002 Sep; 34(9): 1523-8. PMid:12218749 http://dx.doi.org/10.1097/00005768-200209000-00020

[9] Iwamoto J, Otaka Y, Kudo K, Takeda T, Uzawa M, Hirabayashi K. Efficacy of training program for ambulatory competence in elderly women. Keio J Med. 2004 Jun; 53(2): 85-9. PMid:15247512 http://dx.doi.org/10.2302/kjm.53.85

[10] Lundeberg TC. Vibratory stimulation for the alleviation of chronic pain. Acta Physiol Scand Suppl. 1983; 523: 1-51. PMid:6609524

[11] Del Pozo-Cruz B, Hernandez Mocholi MA, Adsuar JC, Parraca JA, Muro I, Gusi N. Effects of whole body vibration therapy on main outcome measures for chronic non-specific low back pain: a single-blind randomized controlled trial. J Rehabil Med. 2011 Jul; 43(8): 689-94. PMid:21687923 http://dx.doi.org/10.2340/16501977-0830

[12] Alentorn-Geli E, Padilla J, Moras G, Lazaro Haro C, Fernandez-Sola J. Six weeks of whole-body vibration exercise improves pain and fatigue in women with fibromyalgia. Journal of alternative and complementary medicine (New York, NY. 2008 Oct; 14(8): 975-81.

[13] Melzack R, Wall PD. Pain mechanisms: a new theory. Science. 1965 Nov 19; 150(699): 971-9. PMid:5320816 http://dx.doi.org/10.1126/science.150.3699.971

[14] Kerr FW. Pain. A central inhibitory balance theory. Mayo Clin Proc. 1975 Dec; 50(12): 685-90. PMid:172744

[15] Guieu R, Tardy-Gervet MF, Roll JP. Analgesic effects of vibration and transcutaneous electrical nerve stimulation applied separately and simultaneously to patients with chronic pain. Can J Neurol Sci. 1991 May; 18(2): 113-9. PMid:1712660

[16] Norregaard J, Bulow PM, Lykkegaard JJ, Mehlsen J, Danneskiold-Samsooe B. Muscle strength, working capacity and effort in patients with fibromyalgia. Scand J Rehabil Med. 1997 Jun; 29(2): 97-102. PMid:9198259

[17] Hakkinen K, Pakarinen A, Hannonen P, Hakkinen A, Airaksinen O, Valkeinen H, et al. Effects of strength training on muscle strength, cross-sectional area, maximal electromyographic activity, and serum hormones in premenopausal women with fibromyalgia. J Rheumatol. 2002 Jun; 29(6): 1287-95. PMid:12064848

[18] Lund E, Kendall SA, Janerot-Sjoberg B, Bengtsson A. Muscle metabolism in fibromyalgia studied by P-31 magnetic resonance spectroscopy during aerobic and anaerobic exercise. Scand J Rheumatol. 2003; 32(3): 138-45. PMid:12892249 http://dx.doi.org/10.1080/03009740310002461

[19] Borman P, Celiker R, Hascelik Z. Muscle performance in fibromyalgia syndrome. Rheumatol Int. 1999; 19(1-2): 27-30. PMid:10651078 http://dx.doi.org/10.1007/s002960050095

[20] Valkeinen H, Hakkinen A, Alen M, Hannonen P, Kukkonen-Harjula K, Hakkinen K. Physical fitness in postmenopausal women with fibromyalgia. Int J Sports Med. 2008 May; 29(5): 408-13. PMid:17960505 http://dx.doi.org/10.1055/s-2007-965818

[21] Mannerkorpi K, Svantesson U, Carlsson J, Ekdahl C. Tests of functional limitations in fibromyalgia syndrome: a reliability study. Arthritis Care Res. 1999 Jun; 12(3): 193-9. http://dx.doi.org/10.1002/1529-0131(199906)12:3<193::AID-ART6>3.0.CO;2-N

[22] Fagnani F, Giombini A, Di Cesare A, Pigozzi F, Di Salvo V. The effects of a whole-body vibration program on muscle performance and flexibility in female athletes. Am J Phys Med Rehabil. 2006 Dec; 85(12): 956-62. PMid:17117001 http://dx.doi.org/10.1097/01.phm.0000247652.94486.92

[23] Bennett RM, Jones J, Turk DC, Russell IJ, Matallana L. An internet survey of 2,596 people with fibromyalgia. BMC Musculoskelet Disord. 2007; 8: 27. PMid:17349056 http://dx.doi.org/10.1186/1471-2474-8-27

[24] Thomas AW, White KP, Drost DJ, Cook CM, Prato FS. A comparison of rheumatoid arthritis and fibromyalgia patients and healthy controls exposed to a pulsed (200 microT) magnetic field: effects on normal standing balance. Neurosci Lett. 2001 Aug 17; 309(1): 17-20. http://dx.doi.org/10.1016/S0304-3940(01)02009-2

[25] Jones KD, Horak FB, Winters-Stone K, Irvine JM, Bennett RM. Fibromyalgia is associated with impaired balance and falls. J Clin Rheumatol. 2009 Feb; 15(1): 16-21. PMid:19125137 http://dx.doi.org/10.1097/RHU.0b013e318190f991

[26] Watson NF, Buchwald D, Goldberg J, Noonan C, Ellenbogen RG. Neurologic signs and symptoms in fibromyalgia. Arthritis Rheum. 2009 Sep; 60(9): 2839-44. PMid:19714636 http://dx.doi.org/10.1002/art.24772

[27] Heredia Jimenez JM, Aparicio Garcia-Molina VA, Porres Foulquie JM, Delgado Fernandez M, Soto Hermoso VM. Spatial-temporal parameters of gait in women with fibromyalgia. Clin Rheumatol. 2009 May; 28(5): 595-8. PMid:19169619 http://dx.doi.org/10.1007/s10067-009-1101-7

[28] Schmidt-Wilcke T, Luerding R, Weigand T, Jurgens T, Schuierer G, Leinisch E, et al. Striatal grey matter increase in patients suffering from fibromyalgia--a voxel-based morphometry study. Pain. 2007 Nov; 132 Suppl 1: S109-16. PMid:17587497 http://dx.doi.org/10.1016/j.pain.2007.05.010

[29] McCabe CS, Cohen H, Hall J, Lewis J, Rodham K, Harris N. Somatosensory conflicts in complex regional pain syndrome type 1 and fibromyalgia syndrome. Curr Rheumatol Rep. 2009 Dec; 11(6): 461-5. PMid:19922737 http://dx.doi.org/10.1007/s11926-009-0067-4 
[30] Adsuar JC, Olivares PR, del Pozo-Cruz B, Parraca JA, Gusi N. Test-retest reliability of isometric and isokinetic knee extension and flexion in patients with fibromyalgia: evaluation of the smallest real difference. Arch Phys Med Rehabil. 2011; In press. PMid:21872840 http://dx.doi.org/10.1016/j.apmr.2011.04.017

[31] Arnold BL, Schmitz RJ. Examination of Balance Measures Produced by the Biodex Stability System. J Athl Train. 1998 Oct; 33(4):323-7. PMid:16558529

[32] Jones KD, Burckhardt CS, Deodhar AA, Perrin NA, Hanson GC, Bennett RM. A six-month randomized controlled trial of exercise and pyridostigmine in the treatment of fibromyalgia. Arthritis and rheumatism. 2008 Feb; 58(2): 612-22. PMid:18240245 http://dx.doi.org/10.1002/art.23203

[33] Tomas-Carus P, Hakkinen A, Gusi N, Leal A, Hakkinen K, Ortega-Alonso A. Aquatic training and detraining on fitness and quality of life in fibromyalgia. Med Sci Sports Exerc. 2007 Jul; 39(7): 1044-50. PMid:17596770 http://dx.doi.org/10.1249/01.mss.0b0138059aec4

[34] Shrout PE, J.L. F. Intraclass correlations: Uses in assessing rater reliability. Psychological Bulletin. 1979; 86(2): 420-8. http://dx.doi.org/10.1037/0033-2909.86.2.420

[35] Weir JP. Quantifying test-retest reliability using the intraclass correlation coefficient and the SEM. J Strength Cond Res. 2005 Feb; 19(1): 231-40. PMid:15705040

[36] Altman DG, Machin D, Bryant TN, Gardner MJ. Statistics with confidence. Confidence intervals and statistical guidelins. Bristol: British Medical Journal. 2000.

[37] Batterham AM, Hopkins WG. Making meaningful inferences about magnitudes. Int J Sports Physiol Perform. 2006 Mar; 1(1): 50-7. PMid:19114737

[38] Sanudo B, de Hoyo M, Carrasco L, McVeigh JG, Corral J, Cabeza R, et al. The effect of 6-week exercise programme and whole body vibration on strength and quality of life in women with fibromyalgia: a randomised study. Clin Exp Rheumatol. 2010 Nov-Dec; 28(6 Suppl 63): S40-5. PMid:21122265

[39] Olivares PR, Gusi N, Parraca JA, Adsuar JC, Del Pozo-Cruz B. Tilting whole body vibration improves quality of life in women with fibromyalgia: a randomized controlled trial. Journal of alternative and complementary medicine (New York, NY. 2011 Aug; 17(8): 723-8.

[40] Gusi N, Tomas-Carus P. Cost-utility of an 8-month aquatic training for women with fibromyalgia: a randomized controlled trial. Arthritis research \& therapy. 2008; 10(1): R24. PMid:18294367 http://dx.doi.org/10.1186/ar2377

[41] Redondo JR, Justo CM, Moraleda FV, Velayos YG, Puche JJ, Zubero JR, et al. Long-term efficacy of therapy in patients with fibromyalgia: a physical exercise-based program and a cognitive-behavioral approach. Arthritis and rheumatism. 2004 Apr 15; 51(2): 184-92. PMid:15077258 http://dx.doi.org/10.1002/art.20252

[42] Gowans SE, Dehueck A, Voss S, Silaj A, Abbey SE. Six-month and one-year followup of 23 weeks of aerobic exercise for individuals with fibromyalgia. Arthritis and rheumatism. 2004 Dec 15; 51(6): 890-8. PMid:15593364 http://dx.doi.org/10.1002/art.20828

[43] King SJ, Wessel J, Bhambhani Y, Sholter D, Maksymowych W. The effects of exercise and education, individually or combined, in women with fibromyalgia. The Journal of rheumatology. 2002 Dec; 29(12): 2620-7. PMid:12465163

[44] Bruyere O, Wuidart MA, Di Palma E, Gourlay M, Ethgen O, Richy F, et al. Controlled whole body vibration to decrease fall risk and improve health-related quality of life of nursing home residents. Archives of physical medicine and rehabilitation. 2005 Feb; 86(2): 303-7. PMid:15706558 http://dx.doi.org/10.1016/j.apmr.2004.05.019

[45] Bautmans I, Van Hees E, Lemper JC, Mets T. The feasibility of Whole Body Vibration in institutionalised elderly persons and its influence on muscle performance, balance and mobility: a randomised controlled trial [ISRCTN62535013]. BMC Geriatr. 2005; 5: 17. PMid:16372905 http://dx.doi.org/10.1186/1471-2318-5-17

[46] Bogaerts A, Delecluse C, Boonen S, Claessens AL, Milisen K, Verschueren SM. Changes in balance, functional performance and fall risk following whole body vibration training and vitamin D supplementation in institutionalized elderly women. A 6 month randomized controlled trial. Gait Posture. 2011 Jan 19. PMid:21256028 http://dx.doi.org/10.1016/j.gaitpost.2010.12.027

[47] Delecluse C, Roelants M, Verschueren S. Strength increase after whole-body vibration compared with resistance training. Medicine and science in sports and exercise. 2003 Jun; 35(6): 1033-41. PMid:12783053

http://dx.doi.org/10.1249/01.MSS.0000069752.96438.B0

[48] Roelants M, Delecluse C, Goris M, Verschueren S. Effects of 24 weeks of whole body vibration training on body composition and muscle strength in untrained females. International journal of sports medicine. 2004 Jan; 25(1): 1-5. PMid:14750005 http://dx.doi.org/10.1055/s-2003-45238

[49] Verschueren SM, Roelants M, Delecluse C, Swinnen S, Vanderschueren D, Boonen S. Effect of 6-month whole body vibration training on hip density, muscle strength, and postural control in postmenopausal women: a randomized controlled pilot study. $\mathrm{J}$ Bone Miner Res. 2004 Mar; 19(3): 352-9. PMid:15040822 http://dx.doi.org/10.1359/JBMR.0301245

[50] Gusi N, Raimundo A, Leal A. Low-frequency vibratory exercise reduces the risk of bone fracture more than walking: a randomized controlled trial. BMC musculoskeletal disorders. 2006; 7: 92. PMid:17137514 http://dx.doi.org/10.1186/1471-2474-7-92 
[51] Ebersbach G, Edler D, Kaufhold O, Wissel J. Whole body vibration versus conventional physiotherapy to improve balance and gait in Parkinson's disease. Archives of physical medicine and rehabilitation. 2008 Mar; 89(3): 399-403. PMid:18295614 http://dx.doi.org/10.1016/j.apmr.2007.09.031

[52] Turbanski S, Haas CT, Schmidtbleicher D, Friedrich A, Duisberg P. Effects of random whole-body vibration on postural control in Parkinson's disease. Res Sports Med. 2005 Jul-Sep; 13(3): 243-56. PMid:16392539 http://dx.doi.org/10.1080/15438620500222588

[53] Lau RW, Teo T, Yu F, Chung RC, Pang MY. Effects of Whole-Body Vibration on Sensorimotor Performance in People With Parkinson Disease: A Systematic Review. Phys Ther. 2011 Jan 6. PMid:21212374 http://dx.doi.org/10.2522/ptj.20100071

[54] Schuhfried O, Mittermaier C, Jovanovic T, Pieber K, Paternostro-Sluga T. Effects of whole-body vibration in patients with multiple sclerosis: a pilot study. Clin Rehabil. 2005 Dec; 19(8): 834-42. PMid:16323382 http://dx.doi.org/10.1191/0269215505cr919oa

[55] Tihanyi TK, Horvath M, Fazekas G, Hortobagyi T, Tihanyi J. One session of whole body vibration increases voluntary muscle strength transiently in patients with stroke. Clin Rehabil. 2007 Sep; 21(9): 782-93. PMid:17875558 http://dx.doi.org/10.1177/0269215507077814

[56] van Nes IJ, Latour H, Schils F, Meijer R, van Kuijk A, Geurts AC. Long-term effects of 6-week whole-body vibration on balance recovery and activities of daily living in the postacute phase of stroke: a randomized, controlled trial. Stroke. 2006 Sep; 37(9): 2331-5. PMid:16902175 http://dx.doi.org/10.1161/01.STR.0000236494.62957.f3

[57] Van Nes IJ, Geurts AC, Hendricks HT, Duysens J. Short-term effects of whole-body vibration on postural control in unilateral chronic stroke patients: preliminary evidence. Am J Phys Med Rehabil. 2004 Nov; 83(11): 867-73. PMid:15502741 http://dx.doi.org/10.1097/01.PHM.0000140801.23135.09

[58] Gowans SE, deHueck A, Voss S, Silaj A, Abbey SE, Reynolds WJ. Effect of a randomized, controlled trial of exercise on mood and physical function in individuals with fibromyalgia. Arthritis and rheumatism. 2001 Dec; 45(6): 519-29. http://dx.doi.org/10.1002/1529-0131(200112)45:6<519::AID-ART377>3.0.CO;2-3

[59] Neumann L, Sukenik S, Bolotin A, Abu-Shakra M, Amir M, Flusser D, et al. The effect of balneotherapy at the Dead Sea on the quality of life of patients with fibromyalgia syndrome. Clin Rheumatol. 2001; 20(1): 15-9. PMid:11254234 http://dx.doi.org/10.1007/s100670170097

[60] Evcik D, Kizilay B, Gokcen E. The effects of balneotherapy on fibromyalgia patients. Rheumatol Int. 2002 Jun; 22 (2): 56-9. PMid:12070676 http://dx.doi.org/10.1007/s00296-002-0189-8

[61] Jentoft ES, Kvalvik AG, Mengshoel AM. Effects of pool-based and land-based aerobic exercise on women with fibromyalgia/chronic widespread muscle pain. Arthritis Rheum. 2001 Feb; 45(1): 42-7. http://dx.doi.org/10.1002/1529-0131(200102)45:1<42::AID-ANR82>3.0.CO;2-A

[62] Gusi N, Tomas-Carus P, Hakkinen A, Hakkinen K, Ortega-Alonso A. Exercise in waist-high warm water decreases pain and improves health-related quality of life and strength in the lower extremities in women with fibromyalgia. Arthritis Rheum. 2006 Feb 15; 55(1): 66-73. PMid:16463415 http://dx.doi.org/10.1002/art.21718

[63] Mannerkorpi K, Ahlmen M, Ekdahl C. Six- and 24-month follow-up of pool exercise therapy and education for patients with fibromyalgia. Scand J Rheumatol. 2002; 31(5): 306-10. PMid:12455823 http://dx.doi.org/10.1080/030097402760375223

[64] Maquet D, Croisier JL, Demoulin C, Crielaard JM. Pressure pain thresholds of tender point sites in patients with fibromyalgia and in healthy controls. Eur J Pain. 2004 Apr; 8(2): 111-7. http://dx.doi.org/10.1016/S1090-3801(03)00082-X

[65] Okumus M, Gokoglu F, Kocaoglu S, Ceceli E, Yorgancioglu ZR. Muscle performance in patients with fibromyalgia. Singapore Med J. 2006 Sep; 47(9): 752-6. PMid:16924355

[66] Rooks DS, Silverman CB, Kantrowitz FG. The effects of progressive strength training and aerobic exercise on muscle strength and cardiovascular fitness in women with fibromyalgia: a pilot study. Arthritis and rheumatism. 2002 Feb; 47(1): 22-8. PMid:11932874 http://dx.doi.org/10.1002/art1.10180

[67] Geel SE, Robergs RA. The effect of graded resistance exercise on fibromyalgia symptoms and muscle bioenergetics: a pilot study. Arthritis and rheumatism. 2002 Feb; 47(1): 82-6. PMid:11932882 http://dx.doi.org/10.1002/art1.10240

[68] Ang DC, Kaleth AS, Bigatti S, Mazzuca S, Saha C, Hilligoss J, et al. Research to Encourage Exercise for Fibromyalgia (REEF): use of motivational interviewing design and method. Contemp Clin Trials. 2011 Jan; 32(1): 59-68. PMid:20828634 http://dx.doi.org/10.1016/j.cct.2010.08.014

[69] Aydog E, Bal A, Aydog ST, Cakci A. Evaluation of dynamic postural balance using the Biodex Stability System in rheumatoid arthritis patients. Clinical rheumatology. $2006 \mathrm{Jul}$; 25(4): 462-7. PMid:16247584 http://dx.doi.org/10.1007/s10067-005-0074-4

[70] Jones KD, King LA, Mist SD, Bennett RM, Horak FB. Postural control deficits in people with fibromyalgia: a pilot study. Arthritis research \& therapy. 2011 Aug 2; 13(4): R127. PMid:21810264 http://dx.doi.org/10.1186/ar3432

[71] Horak FB. Postural orientation and equilibrium: what do we need to know about neural control of balance to prevent falls? Age Ageing. 2006 Sep; 35 Suppl 2: ii7-ii11. PMid:16926210 http://dx.doi.org/10.1093/ageing/afl077 